*Mestranda em Direito pelo Programa de Pós-Graduação em Direito da Universidade do Vale do Rio dos Sinos UNISINOS. Bolsista CAPES/ PROEX. Especialista em Direito Público pela Escola da Magistratura Federal - ESMAFE (2017). Graduada em Ciências Jurídicas e Sociais pela Pontifícia Universidade Católica do Rio Grande do Sul - PUCRS (2015). Atua no SEMEAR - Núcleo de Assessoria Jurídica a Povos Indígenas e a Comunidades Remanescentes Quilombolas - SAJU/UFRGS (2017- atual). E-mail: michelle_monteiro@ terra.com.br.

** Mestranda em Direito pelo Programa de Pós-Graduação em Direito da Universidade do Vale do Rio dos Sinos - UNISINOS. Bolsista CAPES/PROEX. Possui graduação em Direito pela Universidade do Vale do Rio dos Sinos - UNISINOS. E-mail: luanamarinads@gmail.com

***Doutora em Direito Internacional pela UFRGS (2018), com período sanduíche junto à Universidade de Ottawa. Mestre em Direito Público pela Unisinos (2012). Pós-graduada em Relações Internacionais Contemporâneas pela UFRGS (2015), em Direito Internacional Público, Privado e da Integração Regional pela UFRGS (2009) e em Língua Inglesa pela Unilasalle (2008). Professora Adjunta de Direito Internacional da Universidade Federal de Uberlândia. E-mail: tatiafrcardoso@gmail.com

\section{DESOBEDIÊNCIA CIVIL E (IN)EFICÁCIA: UMA ANÁLISE DO MOVIMENTO INDÍGENA CONTRA A PEC N. 215/2000}

\author{
CIVIL DiSOBEDIENCE AND (IN)EFFICIENCY: AN ANALYSIS OF \\ THE INDIGENOUS MOVEMENT AGAINST PEC N. 215/2000
}

\section{Michelle Alves Monteiro* Luana Marina dos Santos** Tatiana de A. F. R. Cardoso Squeff***}

Como citar: MONTEIRO, Michelle Alves; SANTOS, Luana Marina dos; SQUEFF, Tatiana de A.F.R. Cardoso. Desobediência civil e (in)eficácia: uma análise do movimento indígena contra a PEC n. 215/2000. Scientia Iuris, Londrina, v. 25, n. 1, p. 144-162, mar. 2021. DOI: 10.5433/2178-8189.2021v25n1p144. ISSN: $2178-8189$.

Resumo: Esta pesquisa tem como objetivo central fomentar uma reflexão sobre as reais condições para a realização de atos de desobediência civil na sociedade contemporânea, com intuito de promover um enfrentamento efetivo à produção legislativa e às práticas institucionais não democráticas, especialmente no que tange à atuação judicial como limitadora do direito de manifestação. Para tanto, tomar-se-á como base o movimento político organizado por diversas etnias indígenas que, pretendendo proteger seus direitos originários às terras, os quais são garantidos constitucionalmente haja vista a sua intrinsecalidade, atuaram contra uma das primeiras votações da Proposta de Emenda Constitucional (PEC) n. 215. No que tange os aspectos metodológicos utilizados para a construção desta pesquisa, salienta-se que o método de abordagem empregado neste trabalho é o dedutivo e, quanto aos objetivos, o modelo exploratório, pois, partindo dos conceitos de Estado, democracia e desobediência civil, pretende-se descobrir se a sua aplicação aos movimentos indígenas e, logo, em defesa de seus direitos fundamentais, seria factível, especialmente diante da atuação judicial que vem limitando o direito de manifestação.

Palavras-chave: Desobediência civil. Povos Indígenas. Direito Constitucional. PEC 215.

Abstract: The objective of this paper is to encourage reflection on the real conditions of civil disobedience acts in contemporary society, as it may promote an effective confrontation with 
undemocratic legislative production and institutional practices, especially regarding judicial action as a limiting factor on the right to manifestation. To this end, we will examine political movements organized by various indigenous ethnic groups that, intending to protect their original rights to their lands, which are constitutionally guaranteed in view of their intrinsic nature, acted against one of the first votes of Brazilian Constitutional Amendment Proposal (PEC) n. 215. Regarding our methodological process, this research utilized deductive reasoning and its objectives is exploratory because it examines concepts of the State, democracy and civil disobedience, in addition to finding out whether their application to indigenous movements and, therefore, in defense of their fundamental rights, would be feasible, especially in view of the judicial action that has been limiting the right to manifestation.

Keywords: Civil disobedience. Indigenous people. Constitutional law. PEC 215. 


\section{INTRODUÇÃO}

Em que pesem as normas jurídicas procurem se adequar às mais variadas facetas da(s) sociedade(s), o direito nem sempre é capaz de acompanhar o dinamismo da realidade social, dando ensejo aos mais diversos atos de manifestação popular. Não somente sob o aspecto jurídico, mas, principalmente, em razão da instabilidade social e política no mundo contemporâneo, a desobediência civil - considerada como uma forma de pressão legítima-, atua como um instrumento de luta que permite aos indivíduos a defesa de direitos e garantias que se encontram ameaçados ou violados. Ocorre que, por vezes, os indivíduos que se utilizam deste instituto não são vistos pelo Estado e/ou pela produção midiática como sujeitos que se utilizam de meios lícitos para assegurar a proteção de direitos e garantias fundamentais, mas sim como transgressores e violadores de lei.

Não há como compreender o poder que, ao mesmo tempo que deveria nascer do povo, acaba lhe oprimindo, sem fazer jus às poucas reservas jurisdicionais presentes no ordenamento normativo. A partir desta premissa, esta pesquisa comporta, como objetivo central, promover uma reflexão sobre as reais condições para a realização de atos de desobediência civil na sociedade contemporânea, com intuito de promover um enfrentamento realmente efetivo à produção legislativa e às práticas institucionais não democráticas, especialmente no que tange a atuação judicial como limitadora do direito de manifestação. Verificando, como pressuposto base, em que medida a desobediência civil pode estar inserta no ordenamento jurídico sem que isto venha a lhe privar de sua capacidade de ação social.

No intuito de responder o objetivo apresentado, procederemos inicialmente a uma investigação acerca da aplicabilidade deste instituto dentro do ordenamento jurídico brasileiro, analisando seus limites e possibilidades sob uma perspectiva constitucional. Posteriormente, farse-á uma avaliação mais pragmática, identificando situações em que determinados movimentos, a partir da prática da desobediência civil, lograram êxito em atingir seus objetivos finais e iniciais, com a finalidade de identificar a real eficácia deste instituto. Para tanto, tomar-se-á como base o movimento político organizado por diversas etnias indígenas que, no intuito de proteger seus direitos originários às terras -garantidos constitucionalmente-, entraram, de forma organizada, performando e entoando gritos de guerra no Congresso Nacional, durante uma das primeiras votações da PEC 215.

Em que pese o ato, ainda que momentaneamente, tenha obtido sucesso, os indígenas que ali se encontravam foram tratados como vagabundos e selvagens, demonstrando total desrespeito com um povo que procurava garantir um direito constitucionalmente previsto. Assim, nota-se que, dentro de um sistema que se faz pluriétnico e garantidor de direitos humanos, a desobediência civil, quando estas garantias são transgredidas, torna-se uma ferramenta válida e necessária para que sejam efetivados os anseios.

Por fim, no que tange os aspectos metodológicos utilizados para a construção desta pesquisa, salienta-se que o método de abordagem empregado neste trabalho é o dedutivo e, quanto aos objetivos, o modelo exploratório, pois, partindo dos conceitos de Estado, da democracia e do 
instituto da desobediência civil (item 2), pretende-se descobrir se a sua aplicação aos movimentos indígenas e, logo, em defesa de seus direitos fundamentais, seria factível (item 3).

\section{DESCONSTRUINDO OS MUROS DO ESTADO: A DESOBEDIÊNCIA CIVIL}

Antes de compreender o instituto da Desobediência Civil, faz-se necessário, em um primeiro momento, compreender o significado de Estado, aliado aos termos de autoridade e poder, pilares bases para a construção de uma sociedade democrática. A construção de Estado pressupõe uma organização política, em conjunto com a presença da população em um determinado território; tendo, por conseguinte, um instrumento regulador, garantido e regulamentado por meio do exercício de poder. O atual modelo de Estado que paira sob o ordenamento jurídico brasileiro, pautado nos fundamentos de soberania, cidadania, dignidade da pessoa humana, valores sociais do trabalho e da livre iniciativa e pluralismo político, conforme disposições contidas nos incisos I, II, III e IV, do artigo $1^{\circ}$ da Constituição Federal (BRASIL, 1988), respectivamente, preocupou-se em reestabelecer o modelo democrático ferido durante a época ditatorial.

Este modelo estrutural, conforme Sarlet (2012), pressupõe que um autêntico Estado Constitucional se perfectibiliza por meio da outorga do direito à participação dos indivíduos no cenário político-jurídico, a fim de solidificar que, a outorga do poder ao potentado, em regimes democráticos, deve ser gerida do povo para o povo. Neste mesmo aspecto, Bonavides (2003, p. 51), sustenta que, para se garantir uma proteção justa de direitos e garantias fundamentais, necessário se faz a imersão do cidadão como agente político na sociedade, a fim fortalecer seu exercício pleno de cidadania:

Não há democracia sem participação. De sorte que a participação aponta para as forças sociais que vitalizam a democracia e lhe assinam o grau de eficácia e legitimidade no quadro social das relações de poder; bem como a extensão e abrangência desse fenômeno político numa sociedade repartida em classes ou em distintas esferas e categorias de interesses. (BONAVIDES, 2003, p. 51)

Miranda (2011, p. 73) segue esta mesma linha tecendo que "não há povo sem organização de política [...]. É a mesma a origem do povo e da organização - pois o povo não pode conceber-se senão como realidade jurídica", assim, se o Estado Democrático de Direito pressupõe que o poder político pertence ao povo, necessária se faz a participação direta da população para a construção de uma verdadeira democracia.

O processo democrático vigente hoje configura-se em sua forma indireta/representativa, ou seja, é a partir do processo eleitoral, expresso pelo voto de cada membro da sociedade, que o poder (supostamente) emana da vontade da coletividade. Afinal, "[o] voto é espaço de liberdade cidadã, que não pode ser tolhido pelo exigir do outro", garantidor não apenas da própria legitimidade do sistema, como também da expressão do conjunto social, sustentando no poder aquele que melhor os representaria (BRASIL, 2014a).

Isso porque, por vezes, o representante eleito nem sempre é capaz de materializar as 
vontades de (todos os) seus subordinados, acarretando, consequentemente, em um distanciamento entre governantes e governados. A fim de solidificar, Hardt e Negri afirmam que, de fato, em todo o mundo, as queixas sobre os sistemas institucionais internos são constantes e generalizadas, de modo que "o ato de votar frequentemente parece não passar da obrigação de escolher um candidato indesejado, o menor dos males, para nos representar mal por dois, quatro ou seis anos." (HARDT; NEGRI, 2012, p. 342).

Sobre o poder delegado ao governante através do processo democrático, Bobbio, Matteucci e Pasquino (1998, p. 934-935) o caracteriza como um "elemento essencial constitutivo do Estado", de modo que, quando usado de maneira coesa pela autoridade competente, tangencia o consentimento tácito ou expresso de seus governados, uma vez que este "representa sumariamente aquela energia básica que anima a existência de uma comunidade humana num determinado território, conservando-a unida, coesa e solidária". Hanna Arendt (1985, p. 24-27) refere-se ao explicitado por Bobbio, afirmando que o poder não corresponde, apenas, à habilidade humana de agir, "mas de agir em uníssono, em comum acordo". Mais do que isso, a autora acredita que o poder não pode ser considerado como a propriedade de apenas um indivíduo, pois "quando dizemos que alguém está no poder, estamos, na realidade, nos referindo ao fato de encontra-se essa pessoa investida de poder por um certo número de pessoas, para atuar em seu nome".

Ainda que o exercício da soberania se materialize através da eleição de representantes, não existe qualquer garantia de que o governado vá praticar seus atos de acordo com a vontade popular, tampouco de que este vá seguir os princípios e propósitos garantidos constitucionalmente. Para Garcia (2004), a representação política se revela, cada vez mais, insuficiente para a satisfação de sus objetivos, em especial na defesa da própria cidadania. Isso porque, em que pese a palavra "poder" solidifique a possibilidade de agir e de produzir efeitos em prol de um bem comum, esta mesma possibilidade, quando utilizada de maneira desmedida por quem o detém, se traduz, mesmo que acortinada, em formas supostamente legítimas de justificar uma estrutura de dominação social, por meio de uma consciência falsa da realidade.

Conforme Souza Filho (1994), as formas de dominação social, quando alicerçadas em ideologias morais, aliadas àquele que detém o poder, podem se traduzir em ideologias coercitivas que representam um conjunto de "normas ou regras (de conduta) que prescrevem aos membros da sociedade o que devem pensar e como devem pensar, o que devem valorizar e como devem valorizar, o que devem sentir e como devem sentir, o que devem fazer e como devem fazer." (SOUZA FILHO, 1994, p. 113).

É, portanto, possível compreender que, o exercício do poder, quando investido por governantes que não o aplicam de maneira destinada à proteção de direitos e garantias fundamentais, mas que apenas o utilizam com o intuito da prática de dominação, acabam por ferir a noção democrática de um Estado de Direito que se pressupõe constituído por conteúdo não meramente formal, mas sim guiado pelo valor da justiça material. Assim, diante da insegurança jurídica que paira sob o modelo institucional, surgem mecanismos voltados a reestabelecer o funcionamento democrático das instituições e a salvaguardar os direitos inerentes aos cidadãos, especialmente 
dos grupos minoritários ${ }^{1}$, sendo o mais comum o judicial review realizado pela mais alta Corte do Estado (BRASIL, 2016)2. Apesar disso, importante lembrar que

[o] hodierno marco teórico dos diálogos constitucionais repudia a adoção de concepções juriscêntricas no campo da hermenêutica constitucional, na medida em que preconiza, descritiva e normativamente, a inexistência de instituição detentora do monopólio do sentido e do alcance das disposições magnas, além de atrair a gramática constitucional para outros fóruns de discussão, que não as Cortes (BRASIL, 2016).

Quer isso dizer que, para além do enfoque judicial, outros mecanismos poderiam ser utilizados para o mesmo fim, tal como o próprio instituto da Desobediência Civil, que, a partir do manifesto escrito pelo autor Henry Thoreau, em 1849, manifesta-se como uma reformulação do 'Direito de Resistência', podendo ser considerado uma forma democrática de luta em busca da democracia e da igualdade social, que, através do teor de consciência e publicidade, objetiva assegurar direitos e garantias normativas, por meio da não-violência.

Este instituto, construído com pesar ao decorrer da idade contemporânea, logrou êxito em ganhar contribuições significativas, tendo, como protagonista, o autor Henry Thoreau (2002). O autor explica, através de seu manifesto, que o homem, ao se deparar com práticas governamentais que contrariassem seus princípios morais, deveria manter seu real compromisso com a sua consciência, uma vez que a democracia, tal como a conhecemos, não pode ser considerada como o último degrau de aperfeiçoamento em matéria de governo.

Thoreau acreditava que a não-violência poderia ser considerada como a melhor forma de combate às leis que não traduzissem, de alguma forma, valores coletivos e morais a todos os cidadãos, de modo que os indivíduos, ao invés de se rebelarem violentamente, poderiam, apenas, descumprir a obrigação arbitrária que lhes fora imposta, objetivando um caminhar em direção a um sistema onde os indivíduos gozassem de maior independência normativa.

Em que pese Thoreau tenha sido percussor do instituto, anos mais tarde, muitos autores procuraram solidificar e aperfeiçoar o entendimento da Desobediência Civil. Esta pesquisa

1 Especificamente acerca disso, importa lembrar que "[n]o constitucionalismo democrático, as constituições desempenham dois grandes papéis: (i) o de preservar os direitos fundamentais, inclusive e sobretudo das minorias; e (ii) o de assegurar o governo da maioria, cujos representantes foram livremente eleitos. Não é incomum, no mundo plural e complexo em que vivemos, que surjam tensões entre esses dois polos, vale dizer, entre os direitos fundamentais de uma minoria e a vontade da maioria. [...] [Outrossim], [a] circunstância de um grupo ser minoritário não enfraquece, mas antes reforça a pretensão de fundamentalidade dos seus direitos. [...] [Afinal], [...] a proteção das minorias e dos grupos vulneráveis qualifica-se como fundamento imprescindível à plena legitimação material do Estado Democrático de Direito" (BRASIL, 2013).

2 É o entendimento literal do Supremo Tribunal Federal: “A postura particularista do Supremo Tribunal Federal, no exercício da judicial review, é medida que se impõe nas hipóteses de salvaguarda das condições de funcionamento das instituições democráticas, de sorte (i) a corrigir as patologias que desvirtuem o sistema representativo, máxime quando obstruam as vias de expressão e os canais de participação política, e (ii) a proteger os interesses e direitos dos grupos políticos minoritários, cujas demandas dificilmente encontram eco nas deliberações majoritárias" (BRASIL, 2016).

3 'Direito de Resistência' pode ser compreendido como a "[c]apacidade de as pessoas ou os grupos sociais se recusarem a cumprir determinada obrigação jurídica, fundada em razões jurídicas, políticas ou morais [...] é uma realidade constitucional em que são qualificados gestos que indicam enfrentamento por ação ou omissão, do ato injusto das normas jurídicas, do governante, do regime político e também de terceiros" (BUZANELLO, 2001, p. $16)$. 
comporta o entendimento de Costa (1990, p. 64), que assim explica:

A Desobediência Civil deve ser conceituada como o comportamento que os membros da sociedade civil assumem frente ao Estado, questionando normas ou decisões originárias de seus aparelhos, através de ação ou omissão desobedientes à ordem jurídica, mas dentro dos princípios da cidadania, com o intuito de mobilizar a opinião pública para a reforma ou revogação daquelas.

Ao passo que Thoreau acreditava que a desobediência civil poderia evidenciar a necessidade do chamamento à consciência pública, Costa (1990) observa que, o objetivo imediato da desobediência civil é mostrar publicamente a injustiça da lei aplicada, induzindo, assim, o legislador a mudá-la. No mesmo sentido, Bobbio (2004) acrescenta que a desobediência civil precisa ser executada publicamente para garantir o alcance do ato questionado, apelando para própria Constituição, a fim de promover a consolidação dos direitos ali positivados. Para este autor, o instituto da desobediência civil aperfeiçoa o ordenamento, devendo, então, ser executado publicamente para que seja alcançado seu objetivo maior, qual seja, a inovação da ordem posta (BOBBIO, 2004).

Para alguns atores, dentre eles Arendt (2009) e Costa (1990), a desobediência civil desencadearia maiores efeitos quando praticada por um certo número de pessoas com interesses similares, enquanto que, caso fosse praticada por apenas um indivíduo, tratar-se-ia, em verdade, do instituto intitulado como 'objeção de consciência'. Arendt assinala que "a desobediência civil aparece quando um número significativo de cidadãos se convence de que os canais normais para mudanças já não funcionam e as queixas não serão ouvidas nem terão qualquer efeito". Para a autora, quando se está em vias de efetuar mudanças, a desobediência civil mostra-se imprescindível para evitar que o governo "se envolva e persista em modos de agir cuja legalidade e constitucionalidade estão expostos a graves dúvidas.” (ARENDT, 2009).

Costa (1990) também acredita que a desobediência civil possa ser considerada como um "ato ilícito que exige ser aceito como lítico", uma vez que o instituto comporta pontos específicos que buscam "adquirir ou manter um direito de cidadania", além de serem fundamentais para os princípios de uma justiça equilibrada. Para o autor, "[o] limite entre a obrigação de obedecer ao Estado e os direitos oriundos do status de cidadão legitima a atitude do desobediente." (COSTA, 1990).

Ocorre que, ainda que o instituto da desobediência civil procure aperfeiçoar o ordenamento jurídico, trazendo mais "justiça” aos indivíduos ou grupo afetados, é necessário esclarecer que, tendo em vista a pluralidade de indivíduos, é impossível identificar, formalmente, conceitos de "justiça" e "injustiça" inseridos em uma sociedade dinâmica e morfológica. De acordo com Sandel (2011, p. 37), não há conceito que solidifique a definição de "justiça”, uma vez que "[a] vida em sociedade democrática é cheia de divergências entre o certo e o errado, ente justiça e injustiça".

Outrossim, é possível afirmar que existem casos de manifesta injustiça que não abrem margem para questionamentos em torno da lei a ser enfrentada. Tomar-se-á, como exemplo, o 
questionamento de atos normativos que não comportam o aparato axiológico proveniente das leis que versem sobre direitos e garantias fundamentais, inclusive aquelas devidamente previstas em pactos internacionais dos quais o Brasil seja parte, uma vez que, no Estado de Direito Democrático brasileiro, "devem ser intransigentemente respeitados os princípios que garantem a prevalência dos direitos humanos." (BRASIL, 2004).

Então, resta evidente, como supracitado, que a Constituição Federal vigente foi capaz de promover grande avanço no campo dos direitos e garantias; no entanto, sabe-se que, hoje, o grande problema gira em torno da sua não-efetivação. Ainda que o Estado de Direito tivesse tentado, a partir de uma constitucionalização pautada por de um rol de direitos e garantias fundamentais ao indivíduo, este não foi capaz de resolver o problema da opressão, tampouco de garantir, suficientemente, que os indivíduos pudessem participar da cena política tendo como único mecanismo a possível escolha de um representante

É, nesse aspecto, que se insere o instituto da desobediência civil, para que este, além de tentar suprir as deficiências do atual modelo que, infelizmente, ainda não foi capaz de suprir a opressão estatal e tratar com seguridade a arbitrariedade de seus governantes, possa, efetivamente, perfectibilizar e concretizar direitos e garantias fundamentais já positivadas.

Assim, no que diz respeito à legitimidade do ato, muito embora o ordenamento jurídico não admita expressamente a possibilidade do exercício da desobediência, ela se encontra implícita quando o exercício da cidadania enfrenta limitação apenas ao poder do voto. E, como já abarcado, não há como precisar se os canais tradicionais de participação democrática e a própria reivindicação judicial se tornarão suficientes para resguardar a coletividade de um contexto de opressão ou do ato de um governo injusto.

Quer-se, com isso, exemplificar que, em situações de caráter emergencial, a desobediência civil se materializada com um mecanismo verdadeiramente justo, principalmente no que diz respeito à realização da cidadania e à oposição ao poder constituído que não se mostra capaz em garantir a efetivação da ordem constitucional democrática.

Este instituto pode ser visto como um meio sério de questionamento da legislação, uma vez que se apresenta como um exercício de cidadania, que viabiliza a participação popular e objetiva o fortalecimento e o ordenamento jurídico, de modo que os pressupostos para a sua legalidade/ aplicabilidade se encontram por meio de princípios e garantias emanados da Constituição Federal, a exemplo da liberdade, da cidadania, da dignidade da pessoa humana e, o mais perspicaz para o tema, do princípio da soberania popular, que, hoje, "tão atraiçoado e comprometido, é a carta de navegação da cidadania rumo às conquistas democráticas, tanto para esta, como para as futuras gerações." (BONAVIDES, 2003, p. 11).

A desobediência civil, ao longo da história, alcançou inúmeros feitos que marcaram e solidificaram sua eficácia. Entre seus protagonistas, é possível citar Mahatma Gandhi e Martin Luther King ${ }^{4}$ os quais lograram êxito em ilustrar, na prática, o verdadeiro instinto deste instituto,

4 Martin Luther King foi o responsável por gerenciar manifestos organizados e pacíficos na busca de direitos civis para a população negra estadunidense. Mahatma Gandhi, por sua vez, empreendeu campanhas de resistências nãoviolentas, entre elas, o movimento conhecido como "marcha do sal", no qual muitos grupos marcharam juntos em 
fomentando a prática destes exercícios no mundo contemporâneo. É, a partir do protagonismo de atos como esses, que a luta pela positivação de determinados direitos prevalece nos dias atuais, oportunizando aos indivíduos a chance de se aproximar politicamente do poder constituinte, visando a agregar e a garantir os direitos que a legislação vigente preceitua. Hoje, atos de desobediência continuam a ecoar em diversos cantos do mundo, especialmente no Brasil.

Ocorre que, em que pese os indivíduos continuem fomentando e lutando por direitos mais justos e alguns ministros do próprio Supremo Tribunal Federal já tenham se manifestado acerca da necessidade de respeitar-se a liberdade de reunião por esta "constitui[r] prerrogativa essencial dos cidadãos" em "uma sociedade estruturada sob a égide de um regime democrático" (BRASIL, 2014b) ${ }^{5}$, o atual cenário político/midiático insiste em desabonar a imagem daqueles que protagonizam atos desobedientes, não lhe garantindo a efetiva participação da qual fazem jus. ${ }^{6} \mathrm{E}$ importante identificar que muitas destas falácias colocam em cena apenas denominações que são convenientes ao ente estatal, objetivando coibir novos atos que possam ferir e/ou estremecer as estruturas jurídicas normativas que imperam.

E é justamente nesse sentido que o próximo item se insere. A partir de uma análise pragmática, tomar-se-á como base o movimento político organizado por diversas etnias indígenas que, no intuito de proteger seus direitos originários às terras, entraram, de forma organizada, performando e entoando gritos de guerra no Congresso Nacional, durante uma das primeiras votações da PEC 215. Quer-se, com este movimento, identificar em que medida a desobediência civil pode, nos dias de hoje, ser utilizada como um instrumento efetivo para a garantia de direitos fundamentais aos indivíduos, especialmente aos povos indígenas, sem tirar-lhes a dignidade.

\section{POVOS INDÍGENAS E A LUTA POR DIREITOS: UM DESAFIO DIANTE DAS LIMITAÇÕES SOCIAIS NORMATIVAS}

Os povos indígenas sofrem há mais de cinco séculos, desde a invasão dos países ibéricos em território que passou a ser chamado de Brasil, com o modelo civilizatório do Ocidente, que impõe uma racionalidade excludente, pois baseada em valores e concepções racistas (QUIJANO, 2005), e um modelo de vida sustentado no capital, diverso da perspectiva dos povos originários, tendo, essas perspectivas, construído o ordenamento jurídico-normativo; perpetuando, portanto, desigualdades e situações de discriminação.

A imagem do indígena perante a sociedade brasileira é estipulada por três perspectivas distintas. A primeira diz respeito ao papel que o índio representa na época do "descobrimento", aparecendo como "selvagem", cruel, "primitivo", "antropofágico" e até mesmo preguiçosos ${ }^{7}$ de

\footnotetext{
direção ao mar no intuito de colher sal do oceano e distribuí-lo à população local.

5 No mesmo sentido, desde uma perspectiva convencional, $c f$. Brasil (2007).

6 Exemplo dessa situação pode ser encontrada nos protestos realizados em junho de 2013 no Brasil, em que a mídia nacional preferiu reportar a ação violenta de uma parcela dos participantes das passeatas conduzidas em diversas capitais brasileiras, em detrimento da brutalidade policial e das próprias reivindicações políticas dos manifestantes, os quais, registra-se, por vezes - e de maneira bastante abrangente, em que pese o número ínfimo de manifestantes que agiam com violência - eram cunhados de "vândalos" (JORNAL..., 2013; JUNHO..., 2018).

7 Os índios eram tidos como indolentes ou preguiçosos pelo simples fato de resistirem a trabalhar na condição de escravos para os exploradores colonizadores que usurparam suas terras. Rocha (2009, p. 18-19), ironicamente, bem
} 
forma a demonstrar o quão superiores e "civilizados" os colonizadores portugueses eram (ROCHA, 2009). Tal ilustração do índio permanece até os dias de hoje, alimentadas também pela mídia, por indivíduos e grupos econômicos que possuem interesses não só pelas terras indígenas, bem como pelos recursos naturais que elas oferecem. Assim, os índios tornam-se um obstáculo para o grande projeto desenvolvimentista da economia ao se posicionarem contrários à submissão da exploração desigual, elitista, injusta e destrutiva do mercado capitalista; gerando, consequentemente, repressões, intolerância, maus-tratos e hostilidade contra os povos e as lideranças indígenas (LUCIANO, 2006).

O segundo papel que é sustentado na visão do "branco ocidental" (e que pautou toda a política integracionista indígena no Brasil até a Constituição de 1988) advém do momento da catequização, trata-se de uma percepção romantizada. Ali, ele é tido como "infantil", "inocente", "almas virgens", de maneira que eles precisavam da fé e da religião para serem protegidos, para serem salvos (ROCHA, 2009), isto é, deveriam ser submetidos a um processo de aculturação e evangelização, a fim de que, dessa maneira, pudessem ser considerados seres humanos.

A terceira perspectiva que o índio desempenha coincide com o processo de redemocratização do país. Tal visão compreende os índios como sujeitos de direito e, por conseguinte, de cidadania (LUCIANO, 2006). Ocorre que a cidadania em questão diz respeito àquela que se fundamenta em direitos específicos; permitindo, em vista disso, que os povos indígenas, de um lado, possam manter sua própria cultura e forma de vida e, de outro, assegura o direito dos mesmos ao acesso a outras culturas, às suas tecnologias e visões de mundo (LUCIANO, 2006). Sabe-se que a identidade do indígena como tal é dinâmica e varia de região para região, a partir do desenvolvimento histórico do contato (LUCIANO, 2006), sendo a consciência dela tida como critério fundamental para que se possa determinar os grupos (OIT, 2011).

Outrossim, é importante ressaltar que, predominantemente, a sociedade brasileira, adotando uma concepção evolucionista e discriminatória da história da humanidade, persiste em ponderar os índios como sendo de uma cultura de estágio inferiores, de forma que se cria um panorama de integração e assimilação à cultura global (LUCIANO, 2006). Esse cenário tende a gerar um senso de inferioridade aos indígenas, os quais acabam por defrontar-se com dois aspectos: (a) o enfrentamento pela autoafirmação de suas identidades e (b) o reconhecimento de direitos.

No tocante ao reconhecimento de direitos, desde os primórdios do Brasil Colonial é possível observar a insurgência dos povos contra o modelo de Estado que estava sendo implementado. Contudo, é na década de 70 que diversos povos indígenas deram início ao processo pontua que tal recusa nada mais é do que um sinal de saúde mental, mas que o sistema eurocêntrico colonial desde sempre distorce a imagem daquele que o nega.

8 Uma curiosidade a respeito dessa imagem criada pelos europeus acerca da figura do índio é que um dos maiores filósofos do liberalismo, Locke, sustentava a ideia de que, tendo em vista que os indígenas não usavam de forma racional a propriedade das terras, eles desobedeciam a lei natural de Deus, a qual vedava o desperdício da propriedade privada, razão pela qual era legítima a usurpação das propriedades por conta dos colonizadores (SILVA FILHO, 2008).

9 A infantilidade indígena entendida pelos colonizadores (e que ainda muito persiste na cultura brasileira) foi também defendida por Francisco de Vitoria, o qual, para além disso, argumentava que a guerra contra os povos indígenas não deveria ser ocasionada de modo indiscriminado, bem como tanto o papa, quanto o imperador não poderiam impor suas leis sem que existisse um real e justo motivo para isso, já que os índios não eram bestas selvagens, mas sim humanos, homens com pouca instrução e inseridos num estágio infantil, razão pela qual caberia aos cristãos a tutela, a instrução e o governo destes (SILVA FILHO, 2008, p. 347). 
de organizações representativas e políticas, sob a bandeira de assegurar suas terras. Luciano (2006) aponta que a articulação entre tais organizações compõe atualmente o chamado movimento indígena organizado, o qual se trata de uma união de estratégias e ações que tanto as comunidades, quanto as organizações indígenas desenvolvem na proteção de seus direitos e interesses coletivos.

Foi esse movimento que, na Constituinte de 1987/1988, teve um papel crucial para a positivação dos direitos indígenas, bem como para romper com o modelo integracionista até então vigente. Segundo Munduruku (2012), foi a primeira vez ao longo dos, na época, quase 500 anos de Brasil que houve um tratamento diferenciado para a questão indígena e isso se deu em virtude dessa mobilização "extraordinariamente criativa".

Isso porque, até o presente momento, toda a legislação brasileira havia contado com a participação, ainda que mínima, dos povos indígenas.

O que se pode perceber com clareza [...] é que os indígenas, ao longo das sucessivas leis brasileiras e das políticas públicas delineadas e colocadas em prática, foram sempre considerados de um modo assimilador, que desfaz de sua alteridade, levando-a em consideração apenas para demarcar a sua inferioridade. Tal atitude pode ser explicada por todo um desenvolvimento cultural e histórico de caráter uniformizante e etnocêntrico que perfaz a civilização ocidental (SILVA FILHO, 2008, p. 354).

Em 1980, os povos indígenas, com base em um modelo estratégico de exercer a política, criaram a União das Nações Indígenas (UNI), tendo por finalidade não apenas a visibilidade institucional e midiática da questão territorial, como também a luta por sua inclusão no texto constitucional, que estava já sendo debatido. Ao final dos anos 80, Ailton Krenak e Álvaro Tukano (dois atores sociais que exerceram um papel importante e fundamental no movimento social dos povos indígenas) tornaram-se presidentes da UNI, atuando incisivamente na Assembleia Nacional Constituinte, dialogando e intermediando social, cultural e institucionalmente, sendo que Krenak havia autorização especial para transitar pelo Congresso Nacional, participando, inclusive, da votação do capítulo "Dos Índios", o que não foi concedido aos indígenas de diversas etnias que estavam ali presentes (LOPES, 2011).

Ressalta-se um episódio emblemático na história brasileira, ocorrido neste período: o presidente da UNI, Ailton Krenak, teve direito à palavra na Constituinte, proferindo um discurso emocionante enquanto pintava seu rosto de tinta preta de jenipapo, usado pela sua etnia quando se está de luto. O discurso de $\mathrm{Krenak}^{10}$ se deu na Comissão de Sistematização, responsável pelo projeto da Constituição de 1988, denunciando a ganância dos não indígenas em explorar as terras e seus recursos naturais, o que confronta com a cosmovisão dos indígenas, povos que, nas palavras de Ailton, "sempre viveram à revelia de todas as riquezas, um povo que habita casas cobertas de palha, que dorme em esteiras no chão", de modo que não deve o Estado identificar os povos originários como o inimigo dos interesses do Brasil, muito menos como um povo que coloca em

10 Para ter acesso ao vídeo do discurso de Ailton Krenak (ÍNDIO..., 2014). 
risco o desenvolvimento, até porque "o povo indígena tem regado com sangue cada hectare dos oito milhões de quilômetros quadrados deste país".

Assim, graças ao movimento organizado dos índios, bem como ao processo de redemocratização do país, a participação indígena na redação da Carta Política de 1988 foi fundamental para que se pudesse trazer um avanço significativo na questão, reconhecendo os povos indígenas não mais com o fim assimilatório de serem integrados na sociedade, mas aceitálos como são, bem como as suas particularidades, como novos sujeitos coletivos ${ }^{11}$, de acordo com o que bem impulsiona a Convenção n. 169 da OIT, não mais sendo legítima "a presença de indivíduos que tenham como propósito interferir [...] [na] sua cultura”. Afinal, hoje, “[o] objetivo da Constituição é resguardar aos índios um espaço exclusivo onde possam manter e viver as suas tradições." (BRASIL, 2014c).

À vista disso, a nova ordem constitucional instaurada é pluriétnica e multicultural, vez que, em seu artigo 231, é dado reconhecimento aos índios de manterem sua organização social, seus costumes, suas línguas, suas crenças e tradições, bem como o direito originário sobre as terras que tradicionalmente ocupam, de maneira que compete à União a demarcação das mesmas, além de protegê-las e fazer respeitar todos os seus bens. Ou seja, a Carta de 88 acaba por considerar a diversidade cultural como um elemento valorativo a ser amparado e protegido (PEREIRA, 2014).

Compreende-se, a partir da leitura da Constituição ${ }^{12}$, que há uma preocupação em trazer ao cenário jurídico a questão do diferente daquele individuo estabelecido pela sociedade ocidental, como homem, branco, civilizado, cristão. Por causa disso, é que coube, no artigo 215 e em seu parágrafo $1^{\circ}$, ao Estado o dever de garantir a todos o pleno exercício dos direitos culturais, com a valorização e difusão de manifestações das culturas populares, indígenas e afro-brasileiras, e das de outros grupos participantes do processo civilizatório nacional, sendo essencial para que cada comunidade tradicional pudesse exercer seu modo de vida. Pereira (2014) assevera, ainda, que

[t]ratou exaustivamente e em caráter pragmático do território cultural necessário ao exercício desses direitos pelas populações indígenas, emprestando-lhe significado especial, divorciado da pauta patrimonial, porquanto espaço essencial à existência de uma coletividade singular (art. 231, caput e $\S 1^{\circ}$ ). Por essa razão, o texto constitucional assegura a inviolabilidade desse território de forma quase absoluta, admitindo alguma relativização apenas na hipótese de "relevante interesse público da União", a ser definido em lei complementar (art. 231, $\S 6^{\circ}$ ), exigindo-se autorização do Congresso Nacional e aquiescência da comunidade afetada (art. 231, $\S 3^{\circ}$ ).

11 Para Wolkmer (1997, p. 63), essa nova nomenclatura para designar juridicamente a figura do índio como sendo sujeito coletivo foram "identidades coletivas conscientes, mais ou menos autônomos, advindos de diversos estratos sociais, com capacidade de autoorganização e auto-determinação, interligadas por formas de vida com interesses e valores comuns, compartilhando conflitos e lutas cotidianas que expressam privações e necessidades por direitos, legitimando-se como força transformadora do poder e instituidora de uma sociedade democrática descentralizadora, participativa e igualitária".

12 Silva Filho (2008, p. 357) relembra que, apesar de a Constituição de 1988 primar pela alteridade e o reconhecimento das identidades culturais diversas da ocidental, "grande parte dos atores jurídicos permanece insensível a esta mudança de perspectiva. O Código Civil de 2002, apesar de não reproduzir o texto do Código Civil de 1916 quanto à incapacidade relativa dos 'silvícolas', remete à questão para a legislação especial. Contudo, em muitos casos, continua-se ainda a considerar o Estatuto do Índio de 1973 como sendo esta legislação especial, ignorando-se olimpicamente, em prática desgraçadamente comum no Direito brasileiro, o texto constitucional". 
Sobre tal questão territorial, o Constituinte separou os parágrafos $1^{\circ}$ ao $7^{\circ}$ do artigo $231^{13}$ para abordar o tema, estipulando o uso exclusivo do espaço territorial de acordo com os costumes, tradições e usos pelos povos indígenas; garantindo a posse permanente, além do usufruto exclusivo das riquezas do solo, rios e lagos nela existentes ${ }^{14}$; impossibilitando a alienabilidade, disponibilidade e prescritibilidade do direito sobre as terras, de modo que qualquer ato impulsionado por terceiro, que objetiva a ocupação ou a exploração desses territórios e seus recursos, são acatados nulos e extintos, salvo comprovação de boa-fé.

De resto, o artigo 60 dos Atos das Disposições Constitucionais Transitórias (ADCT) fixou o prazo de 5 anos, a partir da promulgação da Constituição, para que a União efetuasse todas as demarcações das terras indígenas, ou seja, até o ano de 1993 as demarcações deveriam ter sido concluídas, o que de fato não aconteceu. Demonstrando o descaso do Estado brasileiro para com os povos originários, bem como o real intento com isso: a não demarcação para o uso das terras pelo agronegócio, política que vem cada vez mais tomando força no contexto atual.

Portanto, a grande questão levantada até o presente momento, que apresentou o panorama político-normativo referente aos povos indígenas, é o desrespeito às normas estabelecidas pela Constituição de 1988. É notória a crise político-democrática-institucional que o Brasil atravessa, tendo como principais atores - e exercendo forte influência - os grandes empresários, os donos do agronegócio e a grande mídia. Assim, coloca-se em risco os direitos garantidos após densa e concisa mobilização popular no decorrer do processo de elaboração da Constituição de 1988 e no período de redemocratização.

Vale evidenciar, nesse sentido, que, muito embora a inovação da Constituição Federal de 1988 no que toca à questão da autodeterminação dos povos, a aceitação e a validação da sua diversidade cultural, além do reconhecimento aos direitos originários das terras, não se vê uma

13 Art. 231. São reconhecidos aos índios sua organização social, costumes, línguas, crenças e tradições, e os direitos originários sobre as terras que tradicionalmente ocupam, competindo à União demarcá-las, proteger e fazer respeitar todos os seus bens. $\S 1^{\circ}$ São terras tradicionalmente ocupadas pelos índios as por eles habitadas em caráter permanente, as utilizadas para suas atividades produtivas, as imprescindíveis à preservação dos recursos ambientais necessários a seu bem-estar e as necessárias a sua reprodução física e cultural, segundo seus usos, costumes e tradições. $\S 2^{\circ}$ As terras tradicionalmente ocupadas pelos índios destinam-se a sua posse permanente, cabendo-lhes o usufruto exclusivo das riquezas do solo, dos rios e dos lagos nelas existentes. $\S 3^{\circ} \mathrm{O}$ aproveitamento dos recursos hídricos, incluídos os potenciais energéticos, a pesquisa e a lavra das riquezas minerais em terras indígenas só podem ser efetivados com autorização do Congresso Nacional, ouvidas as comunidades afetadas, ficando-lhes assegurada participação nos resultados da lavra, na forma da lei. $\S 4^{\circ}$ As terras de que trata este artigo são inalienáveis e indisponíveis, e os direitos sobre elas, imprescritíveis. $\S 5^{\circ}$ É vedada a remoção dos grupos indígenas de suas terras, salvo, "ad referendum" do Congresso Nacional, em caso de catástrofe ou epidemia que ponha em risco sua população, ou no interesse da soberania do País, após deliberação do Congresso Nacional, garantido, em qualquer hipótese, o retorno imediato logo que cesse o risco. $\S 6^{\circ}$ São nulos e extintos, não produzindo efeitos jurídicos, os atos que tenham por objeto a ocupação, o domínio e a posse das terras a que se refere este artigo, ou a exploração das riquezas naturais do solo, dos rios e dos lagos nelas existentes, ressalvado relevante interesse público da União, segundo o que dispuser lei complementar, não gerando a nulidade e a extinção direito a indenização ou a ações contra a União, salvo, na forma da lei, quanto às benfeitorias derivadas da ocupação de boa fé. $\S 7^{\circ}$ Não se aplica às terras indígenas o disposto no art. $174, \S 3^{\circ}$ e $\S 4^{\circ}$ (BRASIL, 1988).

14 " $[\mathrm{N}]$ ão se trata de um direito de propriedade ou de posse — no sentido que os termos assumem no direito privado - , mas de uma figura peculiar, de índole e estatura constitucional, voltada a garantir aos índios os meios materiais de que precisam para proteção e reprodução de sua cultura" (BRASIL, 2013). Até mesmo porque, "sem a garantia de permanência nas terras por ele já tradicionalmente ocupadas, expõe-se ao risco gravíssimo da desintegração cultural, da perda de sua identidade étnica, da dissolução de seus vínculos históricos, sociais e antropológicos e da erosão de sua própria consciência e percepção como integrante de um povo e de uma nação que reverencia os locais místicos de sua adoração espiritual e que celebra, neles, os mistérios insondáveis do universo em que vive” (BRASIL, 2010). 
mudança significativa na realidade vivida pelas sociedades indígenas, vez serem subordinadas a ações afirmativas e a políticas públicas do Estado, especialmente quanto à demarcação das terras indígenas, para que seus direitos e garantias sejam concretizados. O que, em verdade, ocorre é que, para além de não serem efetivadas, tenta-se burlar o sistema para deixar nas mãos da bancada ruralista do Congresso Nacional a realização do procedimento demarcatório, fazendo do Estado, muito antes que um protetor de direitos, um violador de garantias.

A Proposta de Emenda Constitucional (PEC) n. 215 tem por objeto a transferência para o Poder Legislativo, ou seja, para o Congresso Nacional (o que, pela Constituição de 1988, é realizado pelo Poder Executivo, por meio de um procedimento administrativo da FUNAI, com pareceres antropológicos e historiográficos), a palavra final sobre a oficialização de Terras Indígenas (TIs), de maneira que, no campo prático, tal medida serve como instrumento de paralisação dos processo de demarcação de território, entre outros retrocessos não só diretamente atingindo os povos indígenas, como também em matéria socioambiental.

Tal PEC foi proposta em 28 de março de 2000, por Almir Sá do PPB/RR, e segue em tramitação no Congresso Nacional, sofrendo ofensivas tanto de ruralistas, bancada do agronegócio majoritária no parlamento brasileiro, quanto de povos indígenas e organizações da sociedade civil contrárias à aprovação do texto que altera a Constituição (BRASIL, 2000). Segundo a proposta, pretende-se incluir, dentre as competências exclusivas do Congresso Nacional, a aprovação de demarcação das terras tradicionalmente ocupadas pelos índios e a ratificação das demarcações já homologadas, ou seja, enquanto a ADCT estabelecia a demarcação de todas as terras indígenas até 1993, o que - reitera-se - não foi feito, a PEC não só parece agredir a própria separação dos Poderes, acolhida como cláusula pétrea pelos artigos $2^{\circ}$ e 60 , parágrafo $4^{\circ}$, inciso III, da Constituição de 1988, como também - e mais importante ainda - intenta revisar aquelas já demarcadas, provocando um retrocesso no que tange a direitos já adquiridos, segundo o artigo $5^{\circ}$, inciso XXXVI, da Carta Política (outra cláusula pétrea) (BRASIL, 2013), e consequentemente, terminando por gerar uma enorme insegurança para os povos indígenas situados no Brasil.

Por conta disso, em 2013, encabeçada pelo movimento "Abril Indígena”, diversos indígenas ocuparam o Plenário da Câmara dos Deputados, durante a sessão de votação da Comissão Especial para a PEC 215. Tendo sidos duramente barrados na entrada do chamada "casa do povo", no Salão Verde da Câmara dos Deputados, em que foram marchando, em conjunto, cada etnia cantando seu próprio grito de guerra, demonstrando que, ainda que diferentes, ainda que de cosmovisões diversas, os povos indígenas estão juntos lado a lado por um grande ideal: fazer valer a carta constitucional que assegurou seu direito mais básico: a demarcação de terras.

O documentário “Índio é cidadão?" (ÍNDIO..., 2014) aborda, por meio dos vídeos gravados à época, a ocupação da Câmara pelos povos, os quais conseguiram perfurar a barreira de segurança que tentavam impedir sua entrada, gerando um cenário de desespero dos deputados, que saíram correndo de perto dos indígenas ingressantes, como se estes fossem machucá-los. Alguns indígenas entraram dançando e cantando, usando vestimentas próprias de suas etnias, enquanto outros foram ocupando as cadeiras vazias do Plenário. É possível ouvir vozes de parlamentares, ainda que não 
seja identificado, dizendo ao microfone que tal ato era uma "violência", "uma baderna", que os povos indígenas “não respeitam mais nada". Resultado de tal estratégia planejada pelos indígenas foi o encerramento da sessão, com a palavra do Presidente à época, o deputado Henrique Alves, o qual convidou os indígenas ali presentes a se retirarem no prazo de 10 minutos para que pudessem reativar o diálogo institucional e político entre a Câmara e os povos.

A imprensa tratou o caso como invasão ${ }^{15}$, além de o discurso do Presidente da Casa ter sido em tom ameaçador e constrangendo os povos, ao dizer que o Plenário é inviolável. Sonia Guajajara, no documentário acima mencionado, defende que muito pelo contrário, estando os povos originários deste país na Casa do Povo, nada mais justo e digno que sua ocupação, bem como, antes de o Plenário ser inviolável, os direitos dos povos indígenas é que o são.

Pode-se observar a estigmatização dos índios como sendo selvagens e indolentes, imagem fruto de uma concepção racista e colonialista que, muito embora com diversas normas de proteção aos povos e de promoção da diversidade cultural, ainda persiste no imaginário social dos indivíduos. Assim, após muitas discussões, foi criado, em abril de 2013, um Grupo de Trabalho destinado a debater a questão das terras indígenas, com forte participação dos povos (BRASIL, 2000), situação esta que é assegurada por instrumentos normativos, como a Convenção n. 169, da OIT, que prevê a consulta prévia aos interessados, bem como de juristas, como Dalmo Dallari, o qual defendeu a inconstitucionalidade da PEC.

Durante o mês de abril, no Abril Indígenas, os povos fizeram diversas manifestações pacíficas, com danças, músicas, caminhadas, em frente ao Congresso Nacional, sendo constantemente hostilizados. Em ato simbólico, alguns parlamentares, em conjunto a todas etnias ali presentes, queimaram os papéis da PEC 215, comemorando o arquivamento deste, em virtude da determinação do regimento interno. Dessa forma, nota-se que, por meio de uma estratégia política de ocupação pacífica, mediante danças e canções, os povos indígenas tiveram certo avanço ao conter o prosseguimento da PEC para votação, podendo ser ouvidos pelos deputados, bem como pela grande mídia, ainda que esta insistisse em tratá-los como invasores.

Quando não se tem uma efetividade por parte do Estado na consecução dos direitos históricos garantidos na e pela produção legislativa estatal, a insurgência alcança um patamar de necessidade. Portanto, a desobediência civil por partes dos povos indígenas neste caso analisado em tela, pode se constatar por meio dos seguintes elementos: justa causa, abuso de autoridade, lei/ ordem injusta e organização de resistência. A justa causa se dá no fato de que, mesmo diante de uma Constituição Cidadã que garantiu a proteção de direitos humanos dos povos indígenas, persiste uma política institucional de encobrimento do índio. Abuso de autoridade por conta de o Poder Legislativo estar proposto e votando em um instrumento ilegal, tanto porque fere a Constituição e a separação dos poderes, quanto porque transgride instrumentos normativos internacionais dos quais o Brasil incorporou em seu direito interno, como a Convenção n. 169 da OIT.

Por sua vez, a lei/ordem injusta a qual se deve desobedecer é a PEC, que procura estabelecer a demarcação das terras para um espaço de poder que é majoritariamente contrário à existência

$15 C f$., por exemplo, matéria do jornal O Globo sobre o ocorrido (BRAGA; SOUZA; JUNGBLUT, 2013). 
dos povos indígenas e que estão estritamente ligados ao agronegócio e ao capital estrangeiro. A organização de resistência se dá não só pela Articulação dos Povos Indígenas (APIB), quanto pela participação das diversas etnias ao redor do Brasil que atravessam quilômetros para chegar ao palco do poder em Brasília e protestar. A maior reivindicação dos povos indígenas é no sentido de se assegurar a plena efetividade ao texto constitucional, sendo este o grande desafio que está posto, ainda mais nos tempos atuais de claros retrocessos políticos econômicos sociais e culturais.

\section{CONCLUSÃO}

Ante o exposto, resta possível compreender que, em um Estado Democrático de Direito, onde o princípio da soberania popular se coloca como um elemento constitutivo para a construção de sua estrutura, o instituto da Desobediência Civil -considerado como um desdobramento do direito de resistência-, se apresenta como um mecanismo participativo direto de realização da cidadania e de oposição ao poder constituído. Como demonstrado no início deste trabalho, o exercício da participação política indireta dos indivíduos, muitas vezes, falha ao outorgar a determinados indivíduos a tarefa de garantir o texto constitucional, uma vez que estes, quando imbuídos de um poder desmedido, acabam por priorizar determinados direitos e estratos sociais em detrimento de outros, colocando muitos grupos minoritários em situação de emergência, marginalização e desamparo.

Compreende-se, nesse sentido, que a crise de representatividade, bem como o processo inacabado do sistema democrático, fruto da falta de um efetivo estado transacional, pressupõe a participação de novos agentes que, por meio do instituto da desobediência civil, possam lograr êxito em superar determinados paradigmas para aperfeiçoar o sistema democrático que se apresenta, objetivando não diminuir direitos, mas sim lutar pela efetivação daqueles que já estejam garantidos dentro dos diplomas legais do Estado. A análise pragmática aqui abarcada procurou demonstrar que a desobediência civil se mostra efetiva quando utilizada por agentes ou grupos organizados. Porém, em que pese efetiva, ela ainda estremece negativamente as estruturas estatais e midiáticas, porquanto estas insistem em não reconhecer o ato como um meio lícito de reivindicação.

Um exemplo disso foi o movimento político organizado dos povos indígenas que, pelo Abril Indígena, ocuparam o Congresso Nacional em ato contra a votação da PEC 215, que tem por objetivo não só dificultar o processo de demarcação de território, como também passá-lo para a competência do Poder Legislativo, espaço em que a representação indígena é praticamente inexiste, bem como os detentores do poder possuem interesses manifestos nas terras indígenas, vez serem financiados pelo agronegócio ou por uma pretensão civilizatória com a bancada evangélica. Demonstra-se, assim, que o Estado, em que pese pressuponha uma participação democrática, ainda não é capaz de garantir uma verdadeira interferência dos indivíduos na construção de leis mais justas e integrativas. 


\section{REFERÊNCIAS}

ARENDT, Hannah. Da violência. Brasília: Universidade de Brasília, 1985. (Coleção Pensamentos Políticos).

ARENDT, Hannah. A condição Humana. Tradução de Roberto Raposo. Rio de Janeiro: Forense Universitária, 2009.

BOBBIO, Norberto. A era dos direitos. Tradução de Carlos Nelson Coutinho. Rio de Janeiro: Elsevier Editora, 2004.

BOBBIO, Norberto; MATTEUCCI, Nícola; PASQUINO, Gianfranco. Dicionário de política. Brasília: Universidade de Brasília, 1998.

BONAVIDES, Paulo. Teoria constitucional da democracia participativa. 2. ed. São Paulo: Malheiros Editores, 2003.

BRAGA, Isabel; SOUZA, André; JUNGBLUT, Cristiane. Em protesto, índios invadem plenário da Câmara. O Globo, Rio de Janeiro, 16 abr. 2013. Disponível em: https://oglobo.globo.com/ brasil/em-protesto-indios-invadem-plenario-da-camara-8127893. Acesso em: 18 abr. 2019.

BRASIL. [Constituição (1988)]. Constituição da República Federativa do Brasil de 1988. Brasília, DF: Presidência da República, 1988. Disponível em: http://www.planalto.gov.br/ ccivil_03/constituicao/constituicao.htm. Acesso em: 5 maio 2020.

BRASIL. Câmara dos Deputados. PEC 215/2000. Acrescenta o inciso XVIII ao art. 49; modifica o $\S 4^{\circ}$ e acrescenta o $\S 8^{\circ}$ ambos no art. 231, da Constituição Federal. Brasília, DF: Câmara dos Deputados, 2000. Disponível em: https://www.camara.leg.br/proposicoesWeb/ fichadetramitacao?idProposicao=14562. Acesso em: 16 jan. 2020.

BRASIL. Supremo Tribunal Federal. Ação Direta de Inconstitucionalidade n. 4.650. Relator: Min. Luiz Fux. Julgado em: 17 set. 2015. Diário da Justiça Eletrônico, Brasília, DF, 24 fev. 2016.

BRASIL. Supremo Tribunal Federal. Ação Direta de Inconstitucionalidade n. 4.543. Relatora: Min. Cármen Lúcia. Julgado em: 6 nov. 2013. Diário da Justiça Eletrônico, Brasília, DF, 13 out. 2014a.

BRASIL. Supremo Tribunal Federal. Ação Direta de Inconstitucionalidade n. 1.969. Relator: Min. Ricardo Lewandowski. Julgado em: 28 jun. 2007. Diário da Justiça Eletrônico, Brasília, DF, 31 ago. 2007.

BRASIL. Supremo Tribunal Federal. Arguição de Descumprimento de Preceito Fundamental n. 187. Relator: Min. Celso de Mello. Julgado em: 15 jun. 2011. Diário da Justiça Eletrônico, Brasília, DF, 29 maio 2014b.

BRASIL. Supremo Tribunal Federal. Habeas Corpus n. 82.424/RS. Relator: Min. Maurício Corrêa, Julgado em: 17 set. 2003. Diário da Justiça Eletrônico, Brasília, DF, 19 mar. 2004.

BRASIL. Supremo Tribunal Federal. Medida Cautelar no Mandado de Segurança n. 32.262. Relator: Min. Roberto Barroso (dec. monocrática). Julgado em: 20 ago. 2013. Diário da Justiça 
Eletrônico, Brasília, DF, 24 set. 2013.

BRASIL. Supremo Tribunal Federal. Petição em Embargos Declaratórios n. 3.388. Relator: Min. Roberto Barroso. Julgado em: 23 out. 2013. Diário da Justiça Eletrônico, Brasília, DF, 4 fev. 2014c.

BRASIL. Supremo Tribunal Federal. Petição n. 3.388. Relator: Min. Ayres Britto. Voto do Min. Celso de Mello. Julgado em: 19 mar. 2009. Diário da Justiça Eletrônico, Brasília, DF, 1 jul. 2010 .

BUZANELLO, Carlos José. Direito de resistência. Sequência, Florianópolis, v. 22, n. 42, 2001. doi: 10.5007/\%25x. Disponível em: http://www.egov.ufsc.br/portal/sites/default/files/ anexos/1199-1213-1-PB.pdf. Acesso em: 28 abr. 2019.

COSTA, Nelson Nery. Teoria e realidade da desobediência civil. Rio de Janeiro: Forense, 1990.

GARCIA, Maria. Desobediência civil: direito fundamental. São Paulo: Editora Revista dos Tribunais, 2004.

HARDT, Michael; NEGRI, Antônio. Multidão, guerra e democracia na era do Império. Tradução de Clóvis Marques. Rio de Janeiro: Editora Record, 2012.

BOOK. [S. 1.: s. n.], 2010. 1 vídeo (3 min). Publicado pelo canal Leer.

ÍNDIO é cidadão? Brasília, DF: [s.n.], 2014. 1 vídeo (52 min.). Disponível em: https://www. youtube.com/watch?v=kWMHiwdbM_Q. Acesso em: 18 abr. 2019.

JORNAL Nacional: manifestações de junho de 2013. G1, Rio de Janeiro: Rede Globo, 2013. Disponível em: g1.globo.com/videos/t/manifestacoes/v/jornal-nacional-manifestacoes-de-junhode-2013/3567019/. Acesso em: 5 maio 2020.

JUNHO de 2013: as manifestações nas manchetes do G1. G1, Rio de Janeiro: Rede Globo, 13 jun. 2018. Disponível em: https://g1.globo.com/politica/noticia/junho-de-2013-as-manifestacoesnas-manchetes-do-g1.ghtml. Acesso em: 5 maio 2020.

LOPES, Danielle Bastos. O movimento indígena na Assembleia Nacional Constituinte (19841988). 2011. 184 f. Dissertação (Mestrado em História Social) - Universidade do Estado do Rio de Janeiro, Rio de Janeiro, 2011.

LUCIANO, Gersem dos Santos. O índio brasileiro: o que você precisa saber sobre os povos indígenas no Brasil de hoje. Brasília: Ministério da Educação, 2006. (Coleção educação para todos).

MIRANDA, Jorge. Teoria do estado e da Constituição. 3. ed. Rio de Janeiro: Forense, 2011.

MUNDURUKU, Daniel. "Posso ser quem você é sem deixar de ser o que sou": a gênese do movimento indígena brasileiro. In: LUCIANO, Gersem José dos Santos; HOFFMANN, Maria Barroso; OLIVEIRA, Jô Cardoso de (org.). Olhares indígenas contemporâneos. Brasília: Centro Indígena de Estudos e Pesquisas - Cinep, 2012. p. 104-118. 
ORGANiZACÃo INTERnACIONAL DO TRABALHO [OIT]. Convenção sobre Povos Indígenas e Tribais em Países Independentes [Convenção 169]. 27 jun. 1989. Disponível em: http://www.ilo.org/ilolex/cgi-lex/convds.pl?C169. Acesso em: 5 de mai 2020.

PEREIRA, Deborah Macedo Duprat de Britto. O estado pluriétinico. 2014. Disponível em: http://6ccr.pgr.mpf.mp.br/documentos-e-publicacoes/artigos/docs_artigos/estado_plurietnico.pdf. Acesso em: 15 jan. 2020.

ROCHA, Everardo Guimarães. O que é etnocentrismo. São Paulo: Brasiliense, 2009.

SANDEL, Michel. Justiça: o que é fazer a coisa certa. 4. ed. Rio de Janeiro: Civilização Brasileira, 2011.

SARLET, Ingo. A eficácia dos direitos fundamentais: uma teoria Geral dos direitos fundamentais na perspectiva constitucional. Porto Alegre: Livraria do Advogado Editora, 2012.

SILVA FILHO, José Carlos Moreira da. Direitos indígenas e direitos à diferença: o caso do Morro do Osso em Porto Alegre. In: MARTÍNEZ, Alejandro Rosillo (org.). Teoria crítica dos direitos humanos no século XXI. Porto Alegre: EDIPUCRS, 2008.

SOUZA FILHO, Carlos Frederico Marés. O direito envergonhado: o direito e os índios no Brasil. In: GRUPIONI, Luís D. Benzi (org.). Índios no Brasil. Brasília: Ministério da Educação e Desporto, 1994. p. 153-168.

THOREAU, Henry David. A desobediência civil. Porto Alegre: L\&PM Editora, 2002.

WOLKMER, Antonio Carlos. Pluralismo jurídico: fundamentos para uma nova cultura no Direito. São Paulo: Alfa Ômega, 1997.

Como citar: MONTEIRO, Michelle Alves; SANTOS, Luana Marina dos; SQUEFF, Tatiana de A.F.R. Cardoso. Desobediência civil e (in)eficácia: uma análise do movimento indígena contra a PEC n. 215/2000. Scientia Iuris, Londrina, v. 25, n. 1, p. 144-162, mar. 2021. DOI: 10.5433/2178-8189.2021v25n1p144. ISSN: 2178-8189.

Recebido em: 17/01/2020

Aprovado em: 29/06/2020 